\title{
Critical Elements of Foreign Currency Translation: A Worldwide Informational and Accounting Problem
}

\author{
Paul E. Holt \\ Department of Accounting and Finance, \\ Texas A and M University, Kingsville, Campus Box 184, Kingsville, Texas 78363, United States
}

Received 2013-08-07, Revised 2013-11-23; Accepted 2013-11-27

\begin{abstract}
The purpose of this study is to describe and clarify the foreign currency translation problem and to suggest normative criteria by which various methodologies can be tested. The translation problem is presented as a set of four critical questions: (1) whether translation should be done, (2) what numbers to use to translate foreign currency accounts into the reporting currency, (3) what to do with the imbalance that results from translating different accounts with different numbers and (4) what, if anything, to do about changes in price levels. Several normative criteria are recommended for evaluating of various translation methodologies, some related specifically to earnings quality. It is further suggested that when empirical research is done to test various translation methodologies against normative criteria, (1) no translation at all and (2) price parity methodologies should also be tested.
\end{abstract}

Keywords: Currency Translation, Earnings Quality, Price Parity

\section{INTRODUCTION}

When a multinational corporation owns more than $50 \%$ of the voting stock of another corporation, U.S. Generally Accepted Accounting Principles (GAAP) usually requires that the financial statements of the subsidiary be consolidated with those of the parent. If the financial statements of the subsidiary are denominated in a currency other than that of the parent, it is necessary to "translate" the subsidiary's foreign currency denominated accounts into dollars prior to consolidation. Worldwide, numerous methods are used, but the question of how translation ought to be done has not been resolved. Furthermore, the profession has never possessed the empirical knowledge to make an informed policy choice.

\section{PURPOSE OF THE STUDY}

Authoritative bodies are not anxious to make foreign currency translation policy changes, not because the current standard required in a given country is demonstrably a solution to the problem, but because the profession is weary of a difficult problem for which no solution appears to exist. Indeed, it is not clear just what the profession is trying to achieve when translating foreign accounts, nor is the problem itself clearly defined. The purpose of this paper is to describe and clarify the translation problem and to suggest normative criteria by which various translation methodologies should be empirically tested.

\section{METHODOLOGY}

The translation policy choice does not consist of a single decision. Either explicitly or implicitly, four major questions must be answered. The first question, which is generally ignored in the literature, is "Should accountants translate foreign accounts?" If it could be demonstrated that financial statements are more useful for decision making without translation and consolidation, the foreign currency translation problem would be, at long last, solved. But if the profession insists that translation is necessary, three additional, very difficult questions must also be answered. The second question is "What numbers should be used to translate foreign currency accounts into the currency of the parent company?" The 
third is "What should be done with the imbalance that results from translating different accounts with different numbers?" The fourth question is "What, if anything, should be done about changes in price levels"?

Although the latter three questions are clearly interrelated, attempts are sometimes made to compare methods by referring to the wrong questions. For example, in the U.S. it is often argued that the Temporal Rate Method (TRM) of SFAS \#8 results in higher volatility of earnings than the Current-Noncurrent (CNM) method or the Monetary-Nonmonetary (MNM) method (the literature review). Whether the profession uses TRM, CNM, MNM, or some other method relates to the second question. Whether we include translation gains or losses in current income, as in SFAS \#8, or defer them, as in SFAS \#52, relates to the third question. It is the answer to the third question, not the second, that is likely to be the main determinate of variability of earnings.

This study examines these three questions in depth and describes the exchange rate methods most commonly proposed and/or required over a period of decades. Further, it introduces the concept of a price parity construct as a possible replacement for exchange rates, a notion that requires further research.

\section{LITERATURE REVIEW}

The literature review is divided into two parts, one that is intended to represent the massive foreign currency translation literature and one representing earnings quality, an important concept relating to normative criteria.

\subsection{Foreign Currency Translation}

The foreign currency translation literature can be divided into three general categories: (1) studies which are surveys of management perceptions and studies of changes in management behavior, (2) studies of the impact of alternative translation methods on financial statements and (3) market studies.

\subsubsection{Surveys of Management Perceptions and Changes in Management Behavior}

Among the category (1) studies, Rodriguez (1980) surveyed 70 U.S. MNCs and found that managements were non-speculative, defensive with respect to exchange rate variations and reluctant to report translation losses. As a result, they were willing to pay a hedging cost higher than the average exchange depreciation. Griffin and Castanias (1988) observed that managers were motivated to enter the currency futures markets to reduce the fluctuations in reported translation gains and losses. This behavior, while functional for managers, can be dysfunctional to the company since currency futures trading is costly. Houston (1986) found that managements decreased their financial exposure hedging when adopting SFAS \#52. A number of studies reflect managements' displeasure with currency translation rules. Examples are Stanley and Block (1978) and Cooper (1978).

Griffin (1983); Ayers (1986); Berg (1987) and Kelly (1985) and others indicate that large companies with low management ownership are more likely to lobby for or against a proposed change in currency translation rules than smaller companies with higher management ownership. Furthermore, managements do change their behavior based on managements' perceptions of how different currency translation rules may affect financial statements.

Pinto (2002) applied game theory to observe evidence of a degree of managerial opportunism in currency translation methods preferences and suggested a lack of clarity in FASB's classification scheme.

Iatridis (2006) found that early adopters of the U.K. Statement of Standard Accounting Practice No. 20 "Foreign Currency Translation" were generally larger firms. Managements tended to adopt when the adverse economic consequences of adoption were likely to be minimal. They deferred adoption of the standard to influence their financial performance. The timing of the adoption is a matter related to the objectives of the managers in association with the market and economic conditions (Iatridis and Joseph, 2005). Income smoothing, a factor in earnings quality, could be mitigated by appropriate standardization of accounting practice.

\subsubsection{Studies of the Impact on Financial Statements}

Among the category (2) studies are Aggarwal (1978); Biel (1976); Porter (1983) and Selling and Sorter (1983), all of which criticize accounting rules for currency translation. Aggarwal (1978) and Reckers and Taylor (1978) expressed the opinion that SFAS \#8 resulted in financial statements that, in one way or another, did not reflect economic reality. In a simulation study, Rupp (1982) concluded that the temporal method of SFAS \#8 was extremely sensitive to the proportion of debt in the capital structure. Holt (2006) empirically compared the variability of reported earnings resulting from eight foreign currency translation methodologies. The current rate method with non-deferral of translation gains and 
losses resulted in the highest average variability of earnings and price parity methodologies resulted in lower variability than exchange rate methodologies as reflected by the average coefficients of variation of the study companies. However, results were highly firm specific. Holt (2005) examined the comparative information content of return on assets across translation methodologies.

Liu (2006) used an accounting-based equity valuation model for multinational firms to examine the forecasting and valuation properties of foreign currency translation gains and losses. It found that translation gains and losses could be subdivided into a core component and a transitory component. The combined effect was that translation gains and losses were more transitory than transitory earnings.

\subsubsection{Market Studies}

Among the category (3) studies, Bryant and Shank (1977) expected that dysfunctional management behavior would result in significant adverse market reaction. Ziebart and Kim (1987) observed various market reactions to currency translation methods.

Collins and Salatka (1993) concluded that including the foreign currency adjustment in reported earnings, as required by SFAS \#8 (TRM), produced noise which reduced the quality of earnings. Soo and Soo (1994) found that the market incorporated foreign translation gain and loss information reported in stockholders' equity under SFAS 52 when valuing equity securities, but the effect of this information on stock prices was smaller than the effect of other earnings factors. Bartov (1997) found that the SFAS \#52 requirements caused reported earnings to be more relevant for market valuation than SFAS \#8. Wang et al. (2006) suggested that currency-translation differences are at times incrementally relevant to returns.

Kwon et al. (2005) showed that foreign investors generally price exchange risk differently from local investors and that the source and magnitude of differences in exchange risk pricing vary significantly across countries.

Louis (2003) empirically examined the association between change in firm value and the foreign translation adjustment for manufacturing firms. For firms in the manufacturing sector, accounting rules for currency translation usually result in financial statement numbers opposite to the economic effects of exchange rate variations. Thus, the translation adjustment was found to be associated with a loss of value instead of an increase in value. In another empirical study, Pinto (2005) tested the value relevance of foreign currency translation adjustments in an earnings and book value model and observed that foreign currency translation adjustments are significantly valu-relevant when their parameter estimates are allowed to vary in the cross-section.

Iatridis (2005) empirically studied the U.K. stock market response to the implementation of the 1983 U.K. Statement of Standard Accounting Practice (SSAP) No. 20 "Foreign Currency Translation". The stock market appeared to have anticipated the implementation of SSAP 20. There was a positive stock market response in the official year of adoption, resulting from the incomestabilizing effects of the standard. The study also observed a significant relationship between stock returns and the accounting measures in the actual adoption period of the aggregate set of adopters.

Bazaz and Senteney (2001) used an equity valuation model to investigate the extent to which SFAS No. 52 unrealized foreign currency translation gains and losses are reflected in levels of equity security prices. The results indicated that, generally, translation gains and losses are valued, but losses have a greater impact than gains and the value seems to change over time in setting the levels of equity share price.

Chambers (2007) provided evidence in the postSFAS \#130 period that other comprehensive income is priced by investors on a dollar-for-dollar basis. Two components of other comprehensive income, foreign currency translation adjustment and unrealized gains and losses on available-for-sale securities, were found to be priced by investors. But the study suggests that investors pay greater attention to other comprehensive information reported in the statement of changes in equity, rather than in a statement of financial performance.

A conclusion to be drawn from category (3) studies is that accounting methodology changes do often result in an adverse market effect, although such effects are partially the result of managers' changes in behavior based on changes in accounting method.

\subsection{Earnings Quality}

Earnings quality can be reduced by errors and by management manipulation. Aside from honest errors, reported earnings can be manipulated by recording revenues too early or too late, a violation of the recognition principle and by recording expenses too early or too late, a violation of the matching principle. Failing to record liabilities or receivables, or recording them in the wrong accounting period reduces earnings quality.

Earnings quality must reflect the hierarchy of qualitative characteristics of financial information (FASB, 2010) the overriding objective of which is decision usefulness. To achieve this, quality earnings must possess the fundamental characteristics of relevance and faithful representation. One of the components of relevance is predictive value, which 
leads to a number of normative criteria against which foreign currency translation methodologies should be tested. For example, quality earnings can be defined as the ability of the earnings to predict future earnings and cash flows (FE, 2008).

Earnings quality refers to the reasonableness of reported earnings (Knechel et al., 2006). Among the characteristics of earnings listed by McClure (2008) is that the earnings be repeatable. The term used by Revsine et al. (2005) is "sustainable".

Income statement elements such as sales, cost of goods sold and various operating expenses are repeatable (sustainable); they are highly likely to reoccur in the normal course of operations from period to period. Other events, such as gains or losses from the sale of fixed asset and investments generally do not reoccur regularly from period to period and are therefore not sustainable. Extraordinary items clearly are not sustainable.

Income smoothing is highly relevant to earnings quality. It reduces earnings quality because it makes it more difficult, even impossible, for analysts to determine the permanent earnings of a company. But most managers prefer to see a reasonable, steady increase in sales and earnings from period to period, eliminating major increases and declines to the extent possible.

That income smoothing does occur and to a significant degree, is demonstrated by a number of articles, representative of which are Fonseca and Gonzalez (2008); Kanagaretnam et al. (2003) and Lim and Lustgarten (2002).

Zohreh and Ghasab (2012) found that managers could not produce value by engaging in income smoothing. Sulistiyawati (2013) found that the value of the company, its dividend policy and the reputation of the company's auditors do not have any effect on income smoothing.

Chang et al. (2013) provided evidence that income smoothing reduces firm-specific exchange rate exposure. Wang (2013) empirical study shows that investors' perceptions of persistent earnings are inversely related to the level of income smoothing. Further, investors can, through careful research, distinguish between persistent earnings and earnings that have been smoothed.

\section{THE FIRST QUESTION: SHOULD ACCOUNTANTS TRANSLATE FOREIGN ACCOUNTS?}

The main purpose of translating foreign accounts is to make possible the consolidation of parent and foreign subsidiary financial statements. If the profession continues to require consolidation of foreign currency denominated financial statements, the answer to this first question is clearly yes. Since this paper does not deal specifically with the question of consolidation, it is sufficient to point out that substantial arguments against the consolidation of foreign subsidiaries do exist (Holt et al., 1993).

A basic argument against the translation of foreign accounts is that accountants can translate numbers but they cannot translate environments. Differences in business environments are often substantial and are reflected in the individual firm's financial statements. Translating from one currency to another does not solve the problem. For example, a Japanese or Korean Parent company may have a debt to equity ratio that is extremely high by U.S. standards. Such a high ratio does not typically mean that the parent is a highly speculative investment, as it would suggest in the U.S. Instead, the ratio may indicate the Japanese or Korean firm's stability in its own environment and its credit worthiness. It is possible to translate the dollars of a U.S. subsidiary into yen, but the meaning of the translated numbers can be determined only be reference to the environment of the subsidiary.

As another example, for a given Japanese company, earnings per share may be drastically lower than expected of a U.S. company, yet be higher than average in Japan, a phenomenon that is not typically a function of different accounting rules (Aron, 1989). Thus, even when the financial statements of a Japanese subsidiary located in the U.S. are recast into Japanese GAAP, then translated into yen, a Japan-based analyst simply cannot evaluate the subsidiary's results of operations and financial position without reference to the U.S. business and cultural environment.

Although there is no controversy as to how the cash account should be translated (at the exchange rate in effect on the balance sheet date), even the cash account is distorted in translation and consolidation. Exchange rates are prices for conversion of one currency to another. Only if the parent intends to convert foreign currency to home currency and return it to the home environment are exchange rates relevant. For many multinational firms, the intent is to keep the cash in the foreign country to maintain a command over goods and services in that environment. In no way do exchange rates guarantee that the same basket of goods and services available in one country can be purchased in another environment at any price. 


\section{THE SECOND QUESTION:WHAT NUMBER SHOULD BE USED TO TRANSLATE FOREIGN CURRENCY ACCOUNTS?}

Four exchange rate translation methodologies have been required as GAAP in different countries and at different times, as described below.

\subsection{The Current-Noncurrent Method (CNM)}

In CNM, current accounts are translated at the exchange rate which is in effect at the balance sheet date (the current rate). Noncurrent accounts and owners' equity are translated at the exchange rates in effect when those assets were acquired, the liabilities incurred, or the owners' equity elements recorded (the historical rate). The objective of CNM is to reflect the liquidity of the foreign entity's financial position by showing the working capital components in reporting currency equivalents.

This use of the current rate for some accounts and the historical rate for others is meaningful to a parent company which intends to exploit the foreign environment by repatriating funds on a current basis. In recent years, however, most foreign subsidiaries operate relatively independently of the parent and the immediate repatriation of currently generated funds is not the primary purpose of the subsidiary. For this reason, the current-noncurrent method is seldom proposed in recent years as the solution to the translation problem.

\subsection{The Monetary-Nonmonetary Method (MNM)}

In MNM, a different dichotomy is required: monetary items are translated at the current rate and all other balance sheet accounts are translated at the historical rate. Like CNM, MNM is meaningful when the parent company maintains a foreign subsidiary for exploitation and repatriating of funds on a current basis.

\subsection{The Temporal Rate Method (TRM)}

TRM was required by SFAS \#8 (FASB, 1975). Cash, accounts receivable, inventories and investments carried at market, accounts payable and long-term debt are translated at the current rate, whereas inventories and investments carried at cost, fixed and other assets and paid-in capital are translated at the historical rate. The objective of TRM is to preserve the underlying accounting principles of historical cost so that consolidation is possible on a consistent basis.

The major, potential difference between TRM and MNM is the translation of inventories. Since Inventory is nonmonetary, it is translated at historical rates under MNM. Under TRM, inventories might be translated at the current exchange rate, but only if the inventory is carried at market. Companies which carry inventory at cost would translate inventory using historical exchange rates under either TRM or MNM. In practice, there is seldom a major difference in the results generated by the two methodologies.

\subsection{The Current Rate Method (CRM)}

CRM is required by SFAS \#52 (FASB, 1981) and is the current GAAP when the currency of the books and records of the subsidiary is the same as the functional currency. All balance sheet items, with the exception of owners' equity, are translated at the current rate. Owners' equity is translated at historical rates. The objective of CRM is to reflect, in translation, the economic condition and perspective of the local country and to provide information that is generally compatible with the expected economic effects of an exchange rate change on the enterprise's cash flow and equity.

\subsection{The Price Parity Method (PPM)}

The suitability of exchange rates for translation can be questioned. If the goal of a foreign subsidiary is to maximize control over goods and services in the foreign environment, as opposed to the repatriation of funds to the parent company in the parent's currency, exchange rates may not be as appropriate as relative price levels. The 1974 Committee on International Accounting called for an investigation of Purchasing Power Parity (PPP) theory as a possible basis for an alternative to exchange rate methods.

The PPP theory is summarized in Lawrence (1982) in three propositions: (1) PPP is the principal determinant of the long-run equilibrium exchange rate, (2) The shortrun equilibrium exchange rate in any current period is a function of the long-run equilibrium exchange rate in the sense that the latter variable is the principal determinant of and tends to be approached by, the former, (3) The short-run equilibrium exchange rate in any current period is determined principally by the PPP, with the former variable tending to equal the latter.

Under PPM, foreign accounts are restated into the reporting currency, but using price parity relative purchasing power indices instead of exchange rates in an attempt to express command over goods and services in the economy in which the subsidiary entity functions.

The price parity time series to be used for translation is constructed with price indexes. The question of which 
price index to use adds to the complication. The Consumer Price Index (CPI), the Wholesale Price Index (WPI) and the gross national product implicit price deflator are just three of the possibilities.

\subsection{Other Alternatives}

Three other alternatives which have received little attention in the literature include (1) a combination of exchange rates and price parity indices, (2) a cost-based translation method and (3) a method based on interest rates. But consideration of these alternatives generates other challenges. For example, which interest rates should be used in an interest-rates-based method? The prime, rate, discount rate and the rates for federal funds, certificates of deposit, bankers' acceptances and treasury bills are just a few of the possibilities.

An all Current Rate Method (ACRM) can also be proposed, one in which all accounts, assets, liabilities and owners' equity, as well as all income statements items, are translated at the current rate. ACRM would render the third question, discussed below, moot since no translation gains or losses would occur. An advantage to ACRM is that all financial ratios would be the same after translation as before.

\section{THE THIRD QUESTION: WHAT SHOULD BE DONE WITH THE IMBALANCE THAT RESULTS FROM TRANSLATING DIFFERENT ACCOUNTS WITH DIFFERENT UMBERS?}

Since different numbers are used to translate different accounts, (current rates, historical rates, average rates), the resulting parent company currency denominated trial balance will not balance. The change in this imbalance between accounting periods is a "translation gain or loss". The accounting profession has never determined the significance, if any, of this number and therefore does not yet know what should be done with it. There are three theoretical possibilities. The gain or loss could be (1) included in the determination of current net income, (2) deferred and shown as a special cumulative foreign exchange translation adjustment in owners' equity until the subsidiary is disposed of, or (3) deferred until individual elements of the subsidiary, such as specific fixed assets or debt, are disposed of. The translation methodology problem is further complicated by the fact that the answer to this third question is affected by the answer to the second question as described below.
The CNM and MNM methodologies are useful when foreign subsidiaries exist primarily to exploit the foreign environment. Under these circumstances, parent company managers are concerned with measures of funds that could be repatriated in the short term. Under both methods, translation gains and losses may be considered a reasonable measure of the change in remittable currency resulting from changes in exchange rates. Deferring such gains and losses is therefore inconsistent with CNM and MNM.

TRM and MNM are similar, but the purpose of TRM is to preserve the underlying accounting principles of historical cost so that consolidation is possible on a consistent basis. Lorensen (1973) advocated non-deferral of translation gains and losses with TRM because deferral would result in an artificial smoothing of net income that reduces earnings quality. Whether this is true has never been determined; no empirical work exists to support this argument. In fact, it may be just as easily argued that the short-term variations in exchange rates may contain no useful information, that in fact they may result in artificial variability of earnings which results in financial statements that are less useful for decision making.

In the U.S., much of the criticism of SFAS \#8, a TRM methodology, focuses on the requirement that the translation gain or loss be included in current income. Critics perceive that this requirement results in higher variability of earnings which in turn results in lower market values for common stock (Evans and Folks, 1979).

A possible solution to this earnings volatility problem would be a PPM methodology which uses relative price levels instead of exchanges rates. Since the time series of relative price levels is generally less variable than exchange rates, reported earnings under PPM would be less variable. Use of a PPM methodology may satisfy Lorensen's arguments (Lorensen, 1973) as well as the critics of SFAS \#8.

But there is no closure on the issue of variability of reported earnings, nor on the broader issue of what to do with translation gains or losses. The third question remains a major variable in the translation debate (Amernic and Galvin, 1982).

\section{THE FOURTH QUESTION: WHAT, IF ANYTHING, SHOULD BE DONE ABOUT CHANGES IN PRICE LEVELS?}

The fourth decision must be made from among three alternatives: (1) restate/translate (adjust the foreign accounts for foreign country price level changes before translating to the parent currency), (2) translate/restate 
(adjust the accounts for parent country price level changes after they have been translated to the parent currency) and (3) do not adjust for changes in price levels. None of the methodologies required by GAAP in the U.S. has required price level adjustment. Implicitly, the policy choice has always been the third alternative.

In CNM, restatement before translation results in gains and losses from holding noncurrent items which are not likely to be remitted. Since a major goal of CNM is to measure funds which are remittable in the short term, price level adjustment should not be used with CNM. Similar arguments may be applied to MNM.

Lorensen (1973) advocates translate/restate which is consistent with the parent company perspective of TRM. He argues that restate/translate results in information that is not comparable and is unintelligible because amounts are measured in a unit with diverse standards and therefore diverse meanings.

For price parity methodologies, it is possible to restate/translate, translate/restate, or not restate at all. However, restate/translate is more consistent with the foreign environment perspective. If accounts are interested in measuring the command over goods and services in the subsidiary's environment, any restatement for price levels should be made in the subsidiary's currency.

The fourth question of price level adjustment affects the third question of whether to defer translation gains and losses. If a methodology includes restatement, either before or after translation, the argument for deferring the recognition of translation gains and losses is weaker, since the covariance between the exchange rate and the price level is adjusted for. Further, the answer to the fourth question affects the answer to the second question of selection of translation numbers. If restatement occurs before translation, translation must be performed using the current exchange rate or the current relative price level ratio.

\section{CONCLUSION}

Ultimately, the translation methodology policy choice is a normative issue. It has never been clear just what accountants are trying to achieve when they translate foreign accounts into the parent company currency prior to consolidation. But financial reporting is directed toward a major concern of virtually all financial statements users: the ability of a company to generate a positive cash flow from operations. Information relating to this ability is used in decision making. Although the relevance of financial statement information to decision making is clearly the ultimate normative criterion in accounting, the profession has generated virtually no empirical research to indicate which methodology is best based on this criterion.

In the U.S., the Financial Accounting Standards Board (FASB) stated that the purpose of the SFAS \#52 methodology is to generate translated accounts which reflect the economic condition and perspective of the local country and to provide information that is generally compatible with the expected economic effects of an exchange rate change on the enterprise's cash flow and equity. The change from SFAS \#8 to SFAS \#52 was made without any empirical support for the allegation that SFAS \#52 would actually achieve these goals better than did SFAS \#8 or any other methodology and even if it did, there is no empirical evidence that the SFAS \#52 methodology provides information content superior to any other methodology.

It is also clear from the vast literature criticizing SFAS \#8 that many users, in particular managers, hold to the normative criterion of lower variability of earnings. But when the change from SFAS \#8 to SFAS \#52 was made, no empirical evidence existed that demonstrated that SFAS \#52 would result in lower variability of earnings.

The concept of quality earnings leads to a number of normative criteria for test translation methodologies. For example, the use of which translation methodology results in the best predictive relationship between reported earnings and future earnings, future cash flows and market values?

Numerous other normative criteria can be used for testing translation methodologies. The Fischer Black method of selecting accounting alternatives is a possibility, as are firm valuation methods such as the Ohlson firm valuation model.

Finally, until authoritative bodies, practitioners and theoreticians can agree on just what they wish to achieve by translating financial statements denominated in foreign currency and until the profession empirically determines just what happens when we apply different translation methodologies, the translation problem will not be solved. When the necessary research is completed, it is not likely that a single translation methodology will prove superior to all others for all purposes, thus suggesting a rank ordering of normative criteria.

\section{REFERENCES}

Aggarwal, R., 1978. FASB No. 8 and reported results for multinational operations: hazard for managers and investors. J. Account. Audit. Finance, 1: 197-216.

Amernic, J.H. and B.J. B. Galvin, 1982. Foreign currency translation: The debate goes on. CA Mag. 
Aron, P.H., 1989. Japanese research. DAIWA Securities America, Inc.

Ayers, F.L., 1986. Characteristics of firms electing early adoption of SFAS 52. J. Account. Econ., 8: 143-158.

Bartov, E., 1997. Foreign currency exposure of multinational firms: Accounting measures and market valuation. Contemporary Account. Res., 14: 623-652. DOI: $10.1111 / \mathrm{j} .1911-$ 3846.1997.tb00544.x

Bazaz, M.S. and D.L. Senteney, 2001. Value relevance of unrealized foreign currency translation gains and losses. Am. J. Bus., 16: 55-62. DOI: 10.1108/19355181200100012

Berg, G.G., 1987. Early versus late compliance to SFAS 52: An empirical investigation of firm characteristics and the market response. Ph.D. Thesis, Texas A\&M University.

Biel, H.H., 1976. Foreign Woes: Foreign Exchange Losses are Proving Costly for Many Multinationals. Forbes, 1: 95.

Bryant, M. and J.K. Shank, 1977. FASB 8: Questioning the economic impact. The Accounting Forum.

Chambers, D., 2007. An evaluation of SFAS No. 130 comprehensive income disclosures. Rev. Account. Stud., 12: 557-593. DOI: 10.1007/s11142-0079043-2

Chang, F.Y., C.W. Hsin and S.R. Shiah-Hou, 2013. A reexamination of exposure to exchange rate risk: The impact of earnings management and currency derivative usage. J. Bank. Finance, 37: 3243-3257. DOI: 10.1016/j.jbankfin.2013.03.007

Collins, D.W. and W.K. Salatka, 1993. Noisy accounting earnings signals and earnings response coefficients: The case of foreign currency accounting. Contemporary Account. Res., 10: 119-159. DOI: 10.1111/j.1911-3846.1993.tb00385.x

Cooper, K., 1978. The impact of SFAS \#8 on financial management practices. Financ. Executive.

Evans, T.G. and W.R. Folks, 1979. SFAS No 8: Conforming, coping, complaining and correcting. Int. J. Account.

FASB, 1975. Accounting for the translation of foreign currency transactions and foreign currency financial statements. Statement Financial Accounting Standards No. 8. Stamford, Connecticut: FASB.

FASB, 1981. Foreign Currency Translation. Statement of Financial Accounting Standards No. 52. Stamford, Financial Accounting Standards Board.
FASB, 2010. Conceptual Framework for Financial Reporting. In: Qualitative Characteristics of Useful Financial Information, Statement of Financial Accounting Concepts No. 8. FASB, Norwalk, Conn.

FE, 2008. What is earnings quality? Financial Education.

Fonseca, A. and F. Gonzalez, 2008. Cross-country determinants of bank income smoothing by managing loan-loss provisions. J. Bank. Finance, 32: 217-228. DOI: 10.1016/j.jbankfin.2007.02.012

Griffin, P.A. and R.P. Castanias, 1988. Accounting for the Translation of Foreign Currencies: The Effects of Statement 52 on Equity Analysts. Account. Rev., 63: $173-175$.

Griffin, P.A., 1983. Management's preferences for FASB statement no. 52: Predictive ability results. Abacus, 19: 130-138. DOI: 10.1111/j.14676281.1983.tb00244.x

Holt, P., 2005. Comparative information content of return on assets based alternative translation methods. Southwest Bus. Econ. J., 12: 9-17.

Holt, P.E., 2006. The variability of earnings across foreign currency translation methodologies: An empirical comparison. Southwest Bus. Econ. J.

Holt, P.E., C.H. Alworth and G. Rivera, 1993. The case against consolidation of foreign subsidiaries. Proceedings of the 10th Annual Southwest Business Symposium, (SBS' 93), Edmond, Oklahoma.

Houston, C.O., 1986. U.S. Management hedging practices subsequent to the adoption of SFAS No. 52 'foreign currency translation'. Ph.D. Thesis, University of Washington.

Iatridis, G. and N.L. Joseph, 2005. A conceptual framework of accounting policy choice under SSAP 20. Managerial Audit. J., 20: 763-778. DOI: $10.1108 / 02686900510611276$

Iatridis, G.E, 2005. An empirical investigation of the U.K. Stock market response to the implementation of SSAP 20 'foreign currency translation. Investment Manage. Financ. Innovat., 2: $108-126$.

Iatridis, G.E., 2006. Characteristics of UK firms related to timing of adoption of Statement of Standard accounting practice No. 20. Account. Finance, 46: 429-455. DOI: 10.1111/j.1467629X.2006.00176.x 
Kanagaretnam, K., G.J. Lobo and R. Mathieu, 2003. Managerial incentives for income smoothing through bank loan-loss provisions. Rev. Quantitative Finance Account., 20: 63-80. DOI: 10.1023/A:1022187622780

Kelly, L., 1985. Corporate management lobbying on FAS No. 8: Some further evidence. J. Account. Res., 23: 619-632.

Knechel, W.R., B. Ballou and S.E. Salterio, 2006. Auditing: Assurance and Risk. 3rd Edn., Thompson South-Western, Mason, ISBN-10: 0324313187, pp: 857.

Kwon, T.H., S.C. Bae and J.M. Chung, 2005. Do foreign investors price foreign exchange risk differently. J. Financ. Res., 28: 555-573. DOI: 10.1111/j.1475-6803.2005.00139.x

Lawrence, H., 1982. Purchasing power parity and exchange rates: Theory, evidence and relevance. Jai Press, Greenwich, Connecticut.

Lim, S.C. and S. Lustgarten, 2002. Testing for income smoothing using the backing out method: A review of specification issues. Rev. Quantitative Finance Account., 19: 273-290. DOI: 10.1023/A: 1020719624778

Liu, J., 2006. On International Accounting Valuation. J. Int. Account. Res., 5: 67-87. DOI: 10.2308/jiar.2006.5.1.67

Lorensen, L., 1973. Misconceptions about translation. Canadian Chartered Accountant.

Louis, H., 2003. The value relevance of the foreign translation adjustment. Account. Rev., 78: 10271047.

McClure, B., 2008. Earnings: Quality means everything.

Pinto, J.A., 2005. How comprehensive is comprehensive income? The value relevance of foreign currency translation adjustments. J. Int. Financ. Manage. Account., 16: 97-122. DOI: 10.1111/j.1467646X.2005.00113.X

Pinto, J.A.M., 2002. Foreign currency translation method choice: Insights from game theory. J. Applied Bus. Res., 18: 25-34.

Porter, G.A., 1983. Foreign currency accounting FAS 8 or 52? multinationals experiment. Massachusetts CPA Rev. Summer.

Reckers, P.M.J. and M.E. Taylor, 1978. FASB No 8. Does it Distort financial statements. CPA J.

Revsine, L., D. Collins and B. Johnson, 2005. Financial Reporting and Analysis. 3rd Edn., Pearson-Prentice Hall.
Rodriguez, R.M., 1980. Foreign Exchange Management in U.S. Multinationals. 1st Edn., McGraw Hill, Lexington.

Rupp, G.L., 1982. A simulation study of alternative methods for translating statements of autonomous foreign entities. Unpublished Ph.D. Dissertation,. Oklahoma State University.

Selling, T.I. and G.H. Sorter, 1983. FASB Statement No. 52 and Its Implications for Financial Statement Analysis. Financ. Analysts J., 39: 64-69.

Soo, B.S. and L.G. Soo, 1994. Accounting for the multinational firm: Is the translation process valued by the stock market. Account. Rev., 69: 617-637.

Stanley, M.T. and S.B. Block, 1978. Response by United States Financial Managers to Financial Accounting Standard No. 8. J. Int. Busi. Stud., 2: 89-99.

Sulistiyawati, S., 2013. The effect of firm value, dividend policy and the auditor's reputation on income smoothing. Account. Anal. J., 1: 3-3.

Wang, Y., W. Buijink and R. Eken, 2006. The value relevance of dirty surplus accounting flows in the netherlands. Int. J. Account., 41: 387-405. DOI: 10.1016/j.intacc.2006.09.005

Wang, Z., 2013. Measuring Investors' Assessment of Earnings Persistence: Do Investors See Through Smoothed Earnings? Rev. Quantitative Finance Account. DOI: 10.1007/s11156-013-0358-8

Ziebart, D.A. and D.H. Kim, 1987. An examination of the market reactions associated with SFAS No. 8 and SFAS No. 52. Account. Rev., 62: 343-357.

Zohreh, H. and M.L. Ghasab, 2012. The investigation of intangible value created by companies in income smoothing and non income smoothing firms. Financial Account Audit. Records. Winter, 3: 113136. 